guesses", and Karl Popper in The Logic of Scientific Method says, "There is no need even to mention induction", though, of course, he does.

Hypotheses, which are the start of and incentive for the scientific enquiry, are the result of inspiration, insight or, crudely, guesswork, and their deductive consequences are tested by experiment. This alternative view of the nature of scientific method, of Prof. Popper, may be called the hypothetico-deductive method, which was first formulated by William Whewill, the Master of Trinity College, Cambridge, who was a contemporary of Mill. Prof. Medawar, who opens the series of talks, and J.W.N. Watkins, who closes it, make a plea for more casehistories of scientific discoveries.

"The scientific paper is a fraud in the sense that it does give a totally misleading narrative of the processes of thought that go into the making of scientific discoveries.
The inductive format of the scientific paper should be discarded."

To illustrate the thesis which has been summarized here, there are reprints of seven lectures on widely assorted subjects: "The Magnetic Proton", by O. R. Frisch; "The Hunting of the Diesel" (the cyclic variations in its speed), by D. Welbourne; "The Earth's Dynamo", by Sir Edward Bullard; "Paying Attention" (a psychological investigation), by D. Broadbent; "The Edinburgh Spectrophone", by T. Cottrell; "The Computer Botanist" (the use of the Southampton computer in enalysing the results of ecological studies), by W. T. Williams; "The Peenemünde Mystery" (a real 'spy' story), by R. V. Jones.

The little book, which costs only 48 ., ought to be studied by every sixth form and university student, and resesroh worker.
W. I. SUMNER

\title{
UTILIZATION OF GLUCOSE CARBON IN VIVO IN THE MOUSE
}

\author{
By DR. R. VRBA \\ Medical Research Council, Neuropsychiatric Research Unit, Carshalton, Surrey
}

T HERE have been many investigations of the metabolism of glucose labelled with carbon-14 in individual organs and in tissue preparations in vitro, but there is relatively little information about the fate of glucose carbon in the organism as a whole. The object of the investigation described here was to obtain quantitative data on the extent of the conversion of glucose carbon atoms into high-molecular substances in a whole intact animal in vivo and to determine the nature of the 'nonglucose sources' of the respiratory carbon dioxide.

Glucose-U. ${ }^{14} \mathrm{C}$, when injected into an intact animal, is eventually converted almost completely into ${ }^{14} \mathrm{CO}_{2}$; however, this process is not very rapid, since it takes several hours before half the injected glucose $-{ }^{14} \mathrm{C}$ can be recovered in the expired carbon dioxide ${ }^{1}$. It is known that an unestimated part of the glucose carbon is incorporated into substances such as lipids, amino-zcids and proteins, which are not commonly included as intermediates in the generally accepted schemes of oxidation of glucose to carbon dioxide. It has also been shown that only a part of the expired carbon dioxide is formed by the direct oxidation of glucose: a considerable part of the respiratory carbon dioxide comes from what have been described as 'non-glucose sources'2. A rapid and extensive incorporation of glucose carbon atoms into amino-acids in the brain and other organs has been observed to occur in vivo ${ }^{9,7}$, and it has been shown that glucose carbon is utilized for the synthesis of proteins and lipids in the brain and other organs ${ }^{3}$. Although it is known that the utiliza. tion of glucose in various organs can be influenced by fasting, hypoglycæmia, drugs and other factcrs , $^{1,4}$, it is not known how much of the injected glucose is actually assimilated in vivo into high-molecular cell constituents and what is the relative velocity of these processes.

Experiments have now been carried out to account quantitatively for the distribution of the total labelled carbon from glucose-U. ${ }^{14} \mathrm{C}$ in large and small molecules at various intervals after injection of glucose-U. ${ }^{14} \mathrm{C}$. To my knowledge no experiments of this type have previously been published.

Male mice (25-30 g each) were first treated with antibioties to decrease the intestinal flora (neomycin, 250 $\mathrm{mg} / \mathrm{kg}$ in $0.2 \mathrm{ml}$. of water per os, $24 \mathrm{~h}$ before injection). They were then injected intraperitoneally with $15 \mu \mathrm{c}$. glucose-U-14C (as provided by the Radiochemical Centre, Amersham, Buckinghamshire) and killed by dropping in to liquid nitrogen either immediately after the injection (3 control animals) or at intervals ranging from $15 \mathrm{~min}$ to $8 \mathrm{~h}$. During this period each mouse was kept individu- ally in a desiccator, to which 3 gas absorption flasks (containing $15 \mathrm{ml}$. of $2 \mathrm{~N}$ sodium hydroxide each) were attached in series. The third gas absorption bottle was attached to a water pump in such a way that air was constantly sucked into the desiccator and, together with the expired carbon dioxide, was forced successively through the three gas absorption bottles where all expired ${ }^{14} \mathrm{CO}_{2}$ was trapped. The contents of the absorption bottles were then combined, the bottles washed and together with washings made up to $100 \mathrm{ml}$. (fraction carbon dioxide) and, after suitable further dilution, directly plated for counting.

Acid-soluble fraction. The hard-frozen mouse was then powdered in a pre-cooled brass mortar and the homogeneous powder obtained was transferred quantitatively into five volumes of perchloric acid ( 5 per cent $v / v$ ), cooled to $0^{\circ} \mathrm{C}$. The tissue was homogenized for $3 \mathrm{~min}$ using the high-speed 'Ultra-Turax' homogenizer (Janke and Kunkel $\mathrm{KG}$, Staufen i. Br.), with blades rotating at 24,000 r.p.m. The homogenate was centrifuged at 2,500 r.p.m. $(1,500$ $2,000 \mathrm{~g})$ in a M.S.E. Major centrifuge $\left(0^{\circ} \mathrm{C}\right)$, and the sediment re-homogenized in another five volumes of perchloric acid. (All other homogenizations and centrifugations mentioned here were performed in the same way.) This procedure was repeated three times, and the combined supernatants were made up to $500 \mathrm{ml}$. 'This acidsoluble fraction $(40 \mathrm{ml}$.) was neutralized to $p \mathrm{H} 7$ with 60 per cent potassium hydroxide at $0^{\circ} \mathrm{C}$, the precipitated potassium perchlorate was separated by sedimentation overnight in a cold room $\left(0^{\circ} \mathrm{C}\right)$ and centrifuged. The precipitate was re-suspended in $40 \mathrm{ml}$. of water and removed by sedimentation and centrifugation. The combined supernatants (fraction $A . S$.) were made up to volume and plated for counting.

Lipid fraction. (1) The acid-insoluble residue from the above procedure was homogenized in 5 volumes of Bloor's mixture (ethanol-othyl ether, $3: 1 \mathrm{v} / \mathrm{v}$ ) and after standing for $a_{0}$ week at room temperature the suspension was centrifuged. The pellet was then homogenized in 5 volumes of Folch's mixture $\left[\mathrm{CHCl}_{3} / \mathrm{CH}_{3} \mathrm{OH}, 2: 1 \mathrm{v} / \mathrm{v}\right]$ and centrifuged. The combined supernatants wero made up to $500 \mathrm{ml}$. with methanol and suitable portions were plated for counting (fraction $L 1$ ).

(2) The foregoing 'lipid fraction' contains impurities, mainly lipid-bound protein, and therefore it was subjected to the following procedure: $10 \mathrm{ml}$. were neutralized with potassium hydroxide $[60$ per cent $w / v$ ] to the point of decolorization of phenolphthalein and centrifuged in order to eliminate traces of free perchloric acid; the supernatant 
was evaporated to dryness in a boiling-water bath and the dry residue kept at $100^{\circ} \mathrm{C}$ for $30 \mathrm{~min}$. This treatment decomposes the protein-lipid complexes. The dry residue was then re-suspended in $10 \mathrm{ml}$. Folch's mixture and extracted by mechanical rotation for $6 \mathrm{~h}$; the solution was then centrifuged, the sediment re-extracted with another $5 \mathrm{ml}$. of Folch's mixture, and suitable aliquots of the combined supernatant ('purified lipids') plated for counting (fraction $L 2$ ).

Nucleic acid fraction. The residue, after lipid extraction, was homogenized in $50 \mathrm{ml}$. of 10 per cent $(\mathrm{w} / \mathrm{v})$ sodium chloride solution and kept at $100^{\circ} \mathrm{C}$ for $1 \mathrm{~h}$ in a boiling water bath. The tissue was sedimented by centrifugation, and this procedure, recommended for nucleic acid extrac. tion $^{5}$, repeated three times. The combined sodium chloride extracts were treated with 2 vol. of 95 per cent alcohol, the precipitate was washed with alcohol and the supernatants combined and suitable portions were plated for counting. This supernatant $(N . A 1)$ contains radioactive acid-insoluble impurities which are not nucleic acids. The precipitate was dissolved in $5 \mathrm{ml}$. of $0.3 \mathrm{~N}$ potassium hydroxide, kept overnight at $38^{\circ} \mathrm{C}$ to decompose nucleic acids into soluble nucleotides ${ }^{5}$, then potassium hydroxide was eliminated by neutralization with diluted perchloric acid, the precipitated potassium perchlorate washed with $5 \mathrm{ml}$. of water on the centrifuge and the combined supernatants (N.A2) made up to $25 \mathrm{ml}$, with water. Aliquots of this supernatant were plated for counting. An aliquot of fraction $N . A 2$ (which includes tissue-bound glycogen) was then mixed with 5 vol. of ethanol to precipitate 'tissue-bound' glyeogen, which accompanies nucleic acids ${ }^{6}$, but is not hydrolysed during the treatment with potassium hydroxide. The precipitated glycogen was dissolved in $5 \mathrm{ml}$. water and re-precipitated with 5 vol. of alcohol. (The radioactivity of this sediment is included in fraction N.A2.) The combined supernatants, which represent a 'purified nucleic acid fraction' (N.A3), were made up to volume and plated for counting.

Protein fraction. (1) A portion of the dried residue $(500 \mathrm{mg})$ from the pellet, remaining after extraction of the nucleic acid fraction, was homogenized and dissolved in $100 \mathrm{ml}$. of 90 per cent formic acid, and aliquots of this frection $(P I)$ plated for counting.

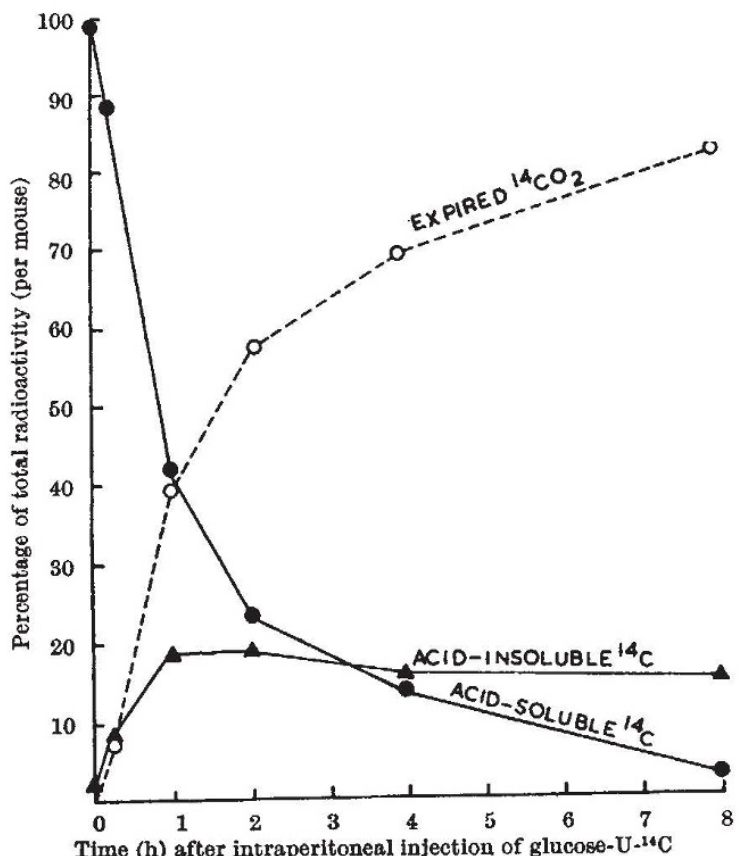

Fig. 1. Distribution of carbon-14 in mice after injection of glucose$\mathrm{U}-14 \mathrm{C}$

Male mice (25-30 g each) were injected with $15 \mu \mathrm{c}$. of glucose-U-14C in $1 \mathrm{ml}$. water in the presence of $0.038 \mathrm{mg}$ carrier glucose and killed (a intervals as indicated in graph) by dropping into liquid nitrogen

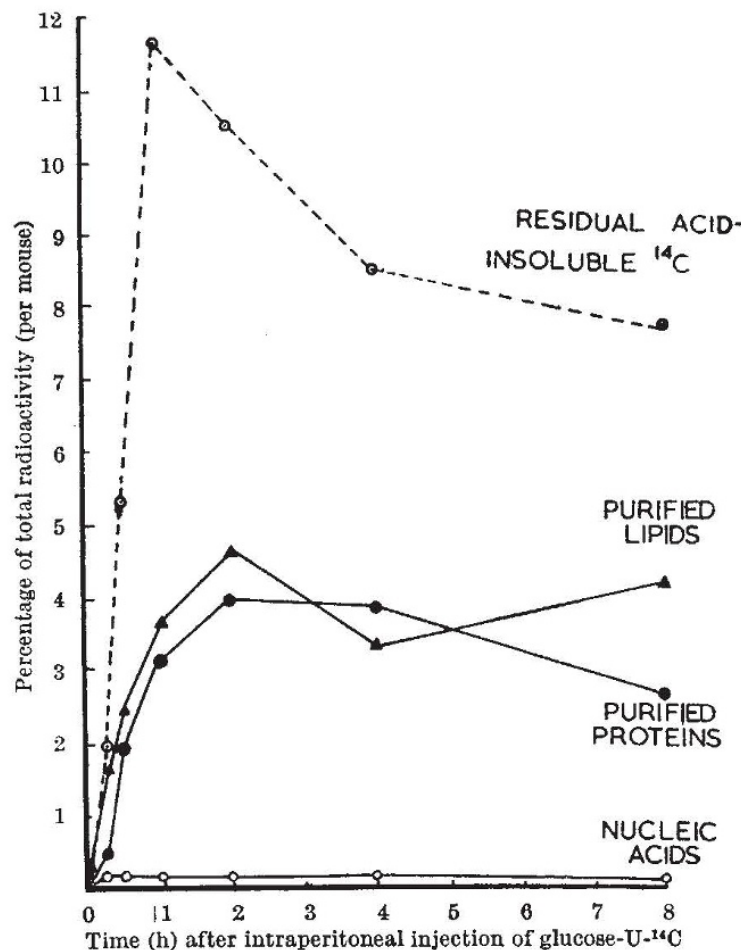

Fig. 2. Incorporation of carbon-14 into acid-insoluble substances in 'Residual acid-insoluble ${ }^{34} \mathrm{C}^{\text {' }}$ includes acid-insoluble ('tissue-bound') glycogen, 'lipid-bound' protein, 'protein-bound' lipids, and the carbon-14 lost during the purification of proteins and lipids. For experimental conditions, see Fig. 1; for details, see text

(2) Another portion of the crude protein fraction was homogenized in $15 \mathrm{ml}$. of trichloroacetic acid $(5$ per cent $\mathrm{w} / \mathrm{v}$ ) and kept in a water bath at $90^{\circ} \mathrm{C}$ for $15 \mathrm{~min}$ with constant stirring. The suspension was centrifuged, the supernatant discarded and the residue homogenized in $10 \mathrm{ml}$. of $6 \mathrm{~N}$ hydrochloric acid and hydrolysed in as sealed 'Pyrex' test-tube for $18 \mathrm{~h}$ at $110^{\circ} \mathrm{C}$. The hydrolysate was evaporated to dryness in vacuo and dissolved in $10 \mathrm{ml}$. of water, neutralized, and passed through a column $(15 \mathrm{~cm} \times 1 \mathrm{~cm})$ of ' $\mathrm{Z} \ominus 0-\mathrm{Karb} 225{ }^{\prime}-\mathrm{H}^{+}$form cation exchange resin. The water effluent $(100 \mathrm{ml}$.) was discarded and the amino-acids were eluted with $200 \mathrm{ml}$. of I $\mathrm{N}$ ammonia solution; the eluate was evaporated to dryness in vacuo, the residue dissolved in water, filtered, made up to volume, and suitable aliquots of this fraction ( $P 2$, 'purified protein') were plated for counting.

All semples were pipetted on to plastic planchets (diam. $2.5 \mathrm{om}$ ), using three different aliquots for calculation of self-absorption, and then dried in desiccators over concentrated sulphuric acid and $\mathrm{NaOH}$-pellets. From each sample 1,000 counts were taken (in triplicate) in a Nuclear Chicago automatic counter and the samples were corrected as necessary for self-absorption and background.

Fate of glucose carbon atoms. The results are expressed in percentage of the total carbon-14 recovered. The total carbon-14 per mouse is obtained from the sum of the following fractions: $\mathrm{CO}_{2}+A . S .+L 1+N \cdot A 1+N \cdot A 2+$ $P 1$. From the three mice killed at zero time, we obtained this way an average of $(1,552 \pm 62) \times 10^{3}$ c.p.m. per mouse. From five mice killed $15 \mathrm{~min}-8 \mathrm{~h}$ after injection of glucose-U. ${ }^{14} \mathrm{C}$ we obtained an average of $(1,560 \pm 42)$ $\times 10^{3}$ c.p.m. per mouse.

The acid-insoluble fraction (Fig. 1) represents the sum of $L 1+N \cdot A 1+N \cdot A 2+P 1$, whereas 'residual acid insoluble ${ }^{14} \mathrm{C}^{\prime}$ (Fig. 2) represents $(L 1+N . A 1+N . A 2+$ $P 1)-(L 2+N \cdot A 3+P 2)$, that is, the sum of unpurified fractions minus the sum of purified frections. The fraction of 'residual acid-insoluble ${ }^{14} \mathrm{C}$ ' includes 'tissuebound' glycogen ${ }^{6}$, 'lipid-bound' proteins, and 'protein- 
bound' lipids. These were eliminated during the purification procedures applied for obtaining 'purified lipids' and 'purified proteins'. The carbon-14 lost during the purification procedures is also included in this fraction.

Fig. I shows that $1 \mathrm{~h}$ after intraperitoneal injection of glucose-U. ${ }^{14} \mathrm{C}$ into the mouse $39 \cdot 3$ per cent of the carbon-14 was eliminated from the organism as ${ }^{14} \mathrm{CO}_{2}$, whereas 18.5 per cent was incorporated into the acid-insoluble fraction. Lipids and proteins isolated after extensive purification contained a minimum of 3.7 and 3.1 per cent respectively of the total carbon-14 (Fig. 2). In view of the short interval this means that a considerable amount of glucose-carbon is rapidly assimilated into proteins and lipids in vivo. $8 \mathrm{~h}$ after intraperitoneal injection of g]ucose-U-14C 82.5 per cent of the labelled carbon was expired as ${ }^{14} \mathrm{CO}_{2}$, but at this time only 2.9 per cent of the carbon-14 remained in the acid-soluble fraction (Fig. 1). Consequently at least 14 per cent of the ${ }^{14} \mathrm{CO}_{2}$, produced from the total oxidation of the injected glucose-U. ${ }^{14} \mathrm{C}$, must be derived from oxidation of the acid-insoluble fraction which includes lipids and proteins. Thus these experiments provide data which show that glucose carbon atoms are in vivo utilized extensively and rapidly in the biosynthesis of proteins and lipids, and that in vivo proteins and lipids are significant as intermediates in the process of oxidation of glucose to carbon dioxide.
Preliminary in vivo experiments have been performed to determine the effect of insulin on the fate of the carbon atoms of glucose.

Crystalline insulin $(0.05-0.40$ U.) was injected subcutaneously into mice $5 \mathrm{~min}$ and $1 \mathrm{~h}$ before the injection of glucose-U-14 C. The mice were killed $1 \mathrm{~h}$ after the latter.

The ${ }^{14} \mathrm{C}$ content of the expired air, the acid-soluble glycogen, the acid-insoluble tissue-bound glycogen and the protein were not significantly affected by insulin.

The rate of incorporation of ${ }^{14} \mathrm{C}$ into lipids was more than doubled.

These experiments will be reported in extenso in due course.

${ }^{1}$ von Holt, C., Schmidt, H., and Feldmann, H., Biochem. Z., 834, 545 (1961). ' Stetten, jun., W. de, Welt, D. D., Ingle, J. D., and Morley, E. H., J. Biol. Chem., 192, 817 (1951). Feller, D. D., Chaikoff, I. L., Strisower, R. H., and Searle, G. L., ibid., 188, 865 (i95i). Feller, D. D., Strisower, E. H.', and Chaikoff, I. L., ibid., 187, 571 (1950). ' Vrba, R., Nature, 195, 663 (1962). Vrba, R., Gaitonde, M. K., and Richter,
D., J. Neurochem., 9, 465 (1962).

- Vrba, R., Bachelard, H. S., and Krawczynski, J., Nature, 197, 869 (1963). Bachelard, H. S., Gaitonde, M. K., Richter, D., and Vrba, R., Lancet, No. 7269, 330 (1962).

- Davidson, J. N., and Smellie, R. N., Biochem. J., 52, 594 (1952).

- Khaikina, B. I., DAN S.S.S.R., 111, 1061 (1956).

'Busch, H., Fujiwara, E., and Keer, L. M., Cancer Res., 20, 50 (1960). Winzler, J. R., Moldaye, K., Rafelson, jun., M. E., and Pearson, H. E., Flexner, L. B., J. Neurochem., i, 78 (1959).

\title{
TRANSFER OF RADIOACTIVITY FROM NUCLEAR TO CYTOPLASMIC RIBONUCLEIC ACID
}

\author{
By PROF. HENRY HARRIS \\ Sir William Dunn School of Pathology, University of Oxford
}

$\mathrm{W}$ HEN cells in which the RNA has been labelled with a radioactive precursor are transferred to non-radioactive medium, radioactivity is gradually lost from the nuclear RNA and, under certain conditions, appears in the cytoplasmic RNA. Some authors take the view that this redistribution of radioactivity between the nuclear and cytoplasmic RNA represents the transfer of stable RNA from nucleus to cytoplasm ${ }^{1-10}$. But there is evidence that the loss of radioactivity from the nuclear RNA in this type of experiment is largely due to intra. cellular breakdown of the labelled nuclear RNA to acidsoluble end-products ${ }^{11-16}$. The experiment which follows supports the latter interpretation and appears to set limits to the extent to which processes other than breakdown might contribute to the loss of radioactivity from the nuclear RNA.

The metabolic interrelationships between adenine and guanine nucleotides in the cell are such that adenine compounds are converted into guanine compounds much more readily than the reverse ${ }^{17}$. When animal cells are grown for a few hours in the presence of $\left({ }^{14} \mathrm{C}\right)$-adenine both the adenine and guanine in the RNA become labelled, the adenine more heavily than the guanine. The pyrimidines are not labelled. It has been pointed out by Scott et al. ${ }^{18}$ that when the radioactive precursor in the medium has been exhausted and the radioactivity remaining in the intracellular RNA precursor pool has been reduced to a negligible fraction of the radioactivity in RNA, the ratio of labelled adenine to labelled guanine in the RNA must remain constant unless breakdown of RNA occurs and the breakdown products undergo interconversion and re-incorporation. If some of the RNA in the cell does undergo breakdown and the breakdown products are re-incorporated, a progressive fall in the ratio of labelled adenine to labelled guanine in the RNA is to be expected.

The experiment recorded here was carried out on HeLa cells growing exponentially in suspension culture. The conditions of culture and the growth medium have been described ${ }^{13}$. The generation time of the cells under these conditions was approximately $20 \mathrm{~h} . \quad\left({ }^{14} \mathrm{C}\right)$-Adenine was added to the culture at a concentration of $0.02 \mu \mathrm{c} . / \mathrm{ml}$. together with enough oarrier adenine to make a final concentration of $10^{-4} \mathrm{M}$. The cells were grown in this medium for $18 \mathrm{~h}$. They were then washed once by centrifugation in non-radioactive medium at $37^{\circ}$ and transferred to pre-warmed non-radioactive medium containing adenosine and guanosine at concentrations of $10^{-3} \mathrm{M}$ and $2 \times 10^{-4} \mathrm{M}$, respoctively. Samples, each containing about $10^{7}$ cells, were taken when the cells were transferred to non-radioactive medium and at intervals thereafter for $8 \mathrm{~h}$. The nuclear RNA was separated from the cytoplasmic RNA by treatment of the cells with phenolsaturated water. The specific activities of the adenine and guanine in the nuclear and cytoplasmic RNA fractions were determined as previously described ${ }^{13}$, and the total amounts of radioactivity in the adenine and guanine of the two fractions were derived from the specific activity measurements.

In Fig. 1, the changes in the total amount of radioactivity per cell in the RNA as a whole and in the RNA adenine and guanine are shown. The curves are corrected to allow for the dilution of radioactivity resulting from the growth of the culture. (The correction factor is given by ekt, where $t=\operatorname{tim} \theta$ and $k=\log 2$ divided by the generation time.) At the beginning of the experiment the RNA adenine contained $137 \times 10^{-6}$ counts per min and the RNA guanine $43 \times 10^{-6}$ counts per min; at the end of the experiment the RNA adenine contained $121 \times 10^{-6}$ counts per min and the RNA guanine $71 \times 10^{-6}$ counts per min. The net amount of radioactivity incorporated into RNA from the precursor pools during the course of the experiment did not exceed $16 \times 10^{-6}$ counts per min/cell, and this incorporation occurred for the most part in the first $2 \mathrm{~h}$. If all the RNA in the cell were stable, the incorporation of this amount of radioactivity from the precursor 